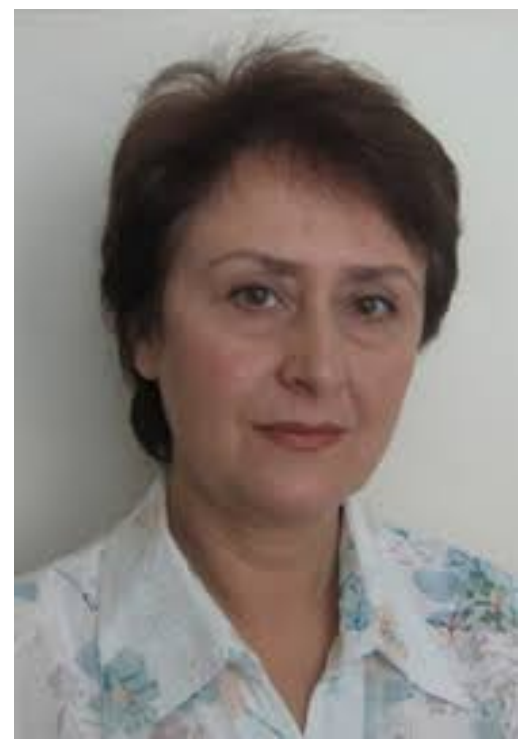

\title{
LINGUOECOLOGICAL APPROACH TO CAPTURING CONCEPTS: A CASE STUDY OF TRANSPARENCY
}

(c) Olena Morozova, DSc (Philology), Professor, Department of English Philology, School of Foreign Languages, V. N. Karazin Kharkiv National University, 4 Svobody Sq., Kharkiv 61022, Ukraine, elena.i.morozova@gmail.com

\section{Summary}

Adopting a linguoecological approach to the study of transdisciplinary concepts, we argue that they may take different shape and/or structure, and even change their nature, in agreement with the environment of their functioning, or their scientific landscape (Yu. S. Stepanov), which comprises the event horizon, or the plane of immanence (G. Deleuze, F. Guattari), and the creator of the concept, or the conceptual persona/aesthetic figure (G. Deleuze, F. Guattari). Different types of concepts are differentiated according to the type of their creator (social vs. personal); they are arranged along the scale 'universal-group-specific-personal'. After that a more granular classification of concept types is carried out according to the sphere of their creator's activities (scientific/logical - everyday philosophical -cultural/aesthetic).Taking the concept transparency as a case, we demonstrate the difference between everyday, scientific, philosophical, and cultural concepts, drawing a distinction 'concepts vs. prospects' as well as 'concepts vs. percepts/affects'.

Key words: affect, concept, linguoecological approach, percept.

\section{Introduction}

A characteristic feature of present-day humanities is that their boundaries are softening and an umbrella discipline - universal anthropology (Степанов, 2007: 13) - gradually emerges in their place. It embraces philosophy, philology, aesthetics, architecture, musicology, cultural studies, political studies, etc. In its turn, the fuzziness of the boundaries brings about scientific objects of a new type - transdisciplinary ones, not confined to a single discipline. 
Yu. S. Stepanov claims that the status of the main object of universal anthropology belongs to concepts (op. cit.: 15), discussions of which range through such disciplines as philosophy, logic, semiotics, history, psychology, economics, literary studies, communication studies, cultural studies, and, most importantly for this research, linguistics.

As O. P. Vorobyova justly remarks (Воробьева, 2013: 10), in the post-Soviet decades, the number of publications addressing the issue of linguistic manifestation of concepts has grown exponentially (see collective monograph studies on concepts: Карасик, Стернин, 2007; Левицкий, Потапенко, 2013; Петлюченко, 2017, etc.). Ironically, the term 'concept' is not at all characteristic of Western scholarly discourse. This has led S. G. Vorkachev to calling concept 'a purely Russian autochthonous formation' (Воркачев, 2011: 71). Nonetheless, the notion itself is pervasive in Western linguistic thought, though concepts appear there under other terminological guises: a mental model (Johnson-Laird, 1983), a cultural model (Holland, Quinn, 1987), a cognitive model (Ruiz de Mendoza, Galera Masegosa, 2014: 75), an idealized cognitive model (Lakoff, 1987), etc.

A. N. Prykhod'ko rightly states that the conceptual branch of linguistics is currently undergoing massive expansion into neighbouring disciplines (Приходько, 2011: 9), enriching them with linguistic methods of obtaining objective data about the 'fine fabrics' - products of the human brain. Yet this expansion backfires on linguistics itself; the concepts formed within neighbouring disciplines (for example, POWER in political science, SIN in theology, BEAUTY in aesthetics, CRIME in jurisprudence, MARKET in economics, EMPATHY in psychology) are treated by researchers on a par with purely linguistic concepts. More specifically, they are usually modelled as 'layered' entities (see the latest version of this model in the book written by its 'ideological father' - V. I. Karasik (Карасик, 2002)) or as frames (see a recent version of the interframe network by its designer S. A. Zhabotynska in (Жаботинская, 2017)).

We side with those scholars who draw a distinction between the following types of concepts: (1) systemic/linguistic, (2) lingocultural, (3) linguocognitive (their views are summed up in the recent publications by O. P. Vorobyova (Воробьева, 2013: 16) and S. I. Potapenko (Потапенко, 2013: 118-123)).

Systemic conceptology, which explores concepts of the first type, acts as a successor of the theory of semantic field 'seasoned with the ideas borrowed from psychology and cognitive science' (ibid.: 122). Scholars pursuing this line of 
research use concepts as classificatory tools serving to group linguistic expressions in a particular way. It means that systemic conceptology is a 'purely linguistic' discipline.

As distinct from systemic conceptologists, scholars representing the second and the third directions in the study of concepts use language as the lens through which concepts can be viewed. It means that the second and the third strains of thought within liguoconceptual studies exceed the confines of linguistics, escaping into the broad sphere of cultural anthropology.

In this paper, adopting an ecological approach to the study of transdisciplinary concepts, we argue that they have the protean quality about them: they readily adopt different shape and structure, and even change their nature in agreement with their environment, or in Yu. S. Stepanov's terms, the 'scientific landscape' (научная ситуация) (Степанов, 2007: 126-127), by which he means the intellectual territory in which the concept has been created. In G. Deleuze and F. Guattari's terms (Делез, Гваттари, 1998), the scientific landscape embraces 'the plane of immanence', or event horizon (op. cit.: 54 et ff.), and conceptual personae (op. cit.: 80 et.ff.), or those who create concepts.

Taking the concept TRANSPARENCY as a case, we demonstrate the difference between logical, everyday, philosophical, and aesthetic concepts. At the same time, we draw a distinction between concept and prospect (a propositional function), after G. Deleuze and F. Guattari (op. cit: 172 et ff.), on the one hand, and concept and percept / affect (op. cit: 207 et ff.), on the other.

\section{Theoretical Prerequisites}

In a most general way, concepts could be defined as mental entities that capture people's experiential knowledge about the world. Such treatment, which is summed up by the formula <concept is a chunk of knowledge>, is prevalent on the vast expanse of post-Soviet linguistics. Yet researchers who draw on the widely quoted definition of concept by E. S. Koubryakova ('concept is an operative informational unit of memory, mental lexicon, and the whole picture of the world in the human psyche' (Кубрякова, 1996: 90)) infrequently overlook the 'operationality' of concepts (Никитин, 2004). Operationality means that concepts not only store chunks of experience, but also show how to put this experience to use when people speak a language. Such 'polyfunctionality' of concepts has led some psychologically oriented researchers to postulating the existence of 
'individual' concepts as opposed to 'collective' ones (Залевская, 2014; Мартынюк, 2017).

The idea of differentiating concepts according to their nature and the sphere of functioning is not new: it was explicitly voiced by philosophers G. Deleuze and F. Guattari in their seminal work "What Is Philosophy?" almost thirty years ago, in 1991 (it was published in Russian in 1998 (Делез, Гваттари, 1998)), developed by a Russian culturologist, linguist, and philosopher Yu. S. Stepanov (Степанов, 2007), and put into linguistic plane by O. I. Morozova (Морозова, 2005; Morozova, 2017).

It could be summed up in the following way. First of all, differentiation should be drawn between scientific notions, which are schematic, bare, dead, and concepts, which are image-like, fleshed, lived-through (Демьянков, 2001). Scientific notions capture characteristic features of objects, phenomena, etc. A good example of a scientific notion would be the definition of a bird, which specifies its genus and species (Делез, Гваттари, 1998: 31). Yet the concept of a bird would consist of a combination of its colouring, singing, poses, etc. (ibid.). It means that concept is an event, but not a thing or entity; it is a mental act, in which human thought runs through the constituents of a concept (ibid.:32). Thus, G. Deleuze and F. Guattari use the terms 'prospect' (op. cit.: 172) and 'concept' to set apart scientific notions, which are logical functions in their essence.

Secondly, concepts should be differentiated according to the degree of emotion associated with them. As Yu. S. Stepanov rightly observes, there is no cognition without emotion (Степанов, 2007: 114) (cf. A. Damasio's (1994) approach to cognition). Due to that, G. Deleuze and F. Guattari draw a distinction between concepts, percepts (the perception and the state of an individual (Делез, Гваттари, 1998: 212), and affects (the emotional experience of an individual, transition from one state to another (ibid.)).

Drawing on the theoretical presumptions above, we propose to arrange mental entities of different types into the scale; it is noteworthy, that there are no rigid borderlines between its constituents. According to Yu. S. Stepanov, there is no demarcation line between the scientific and the artistic (Степанов, 2007: 20); also, universal concepts (such as values) are closer to scientific notions, while nationally specific concepts tend for artistic and philosophic ones. 


\begin{tabular}{|c|c|c|}
\hline Universal & Group-specific & Individual concepts \\
\hline $\begin{array}{l}\text { - } \quad \text { scientific notions } \\
=\text { propspects (e.g. logic, } \\
\text { maths) } \\
\text { - } \quad \text { universal values }\end{array}$ & $\begin{array}{l}\text { - } \quad \text { everyday concepts } \\
\text { - } \quad \text { ethno-/ } \\
\text { gender(etc.)-specific } \\
\text { concepts }\end{array}$ & $\begin{array}{lr}\text { - philosophic } \\
\text { concepts } \\
\text { - } \quad \text { artistic } & \text { concepts } \\
\text { (literature, } & \text { painting, } \\
\text { sculpture, } & \text { music, } \\
\text { architecture) }= & \text { affects } \\
\text { and precepts } & \end{array}$ \\
\hline
\end{tabular}

Fig. 1. Arrangement of concepts according to the nature of their creator

\section{Case Study: TRANSPARENCY}

Transparency as a concept brings together researchers who do not typically meet on common ground: physicists and ecologists, mineralogists and hydrologists, philosophers and political scientists, sociologists and psychologists, analysts of narrative and literary style, linguists examining the uses of linguistic forms in signed and spoken languages, and analysts of gesture accompanying speech. Thus transparency could be called a trans- /or cross-disciplinary concept. Yet, today there is an increasingly popular opinion that it makes no sense to speak of crossdisciplinary research / concepts / phenomena since there are no boundaries between disciplines. Scholarly investigations nowadays take place not within the confines of one science, but within a different system of segmenting knowledge, namely, within the framework of a problem situation. A problem situation is a unit of classifying scientific knowledge. It calls for speaking about the 'core' of a problem situation (Степанов, 1999: 6), and not belonging to a particular science. At the heart of the problem situation under consideration are conditions of achieving transparency of different types and its effects in material and ideal entities (symbolic and non-symbolic).

In line with the tenets of cognitive science which offers a unified explanation of all cognitive capacities of man (perception - visual, auditory, tactile, etc., attention, categorization and conceptualization, affect, memory, reasoning, language, etc.) (Lakoff, 1987; Langacker, 1987), we stick to the assumption that vision and language are inherently rooted in the human body and are products of 
one and the same cognitive mechanism; as such, they are inherently 'viewpointed', or, in the terminology of East European linguistics, anthropocentric.

Transparency (transparence / translucency) is defined as physical property of allowing the transmission of light through a material. This straightforward, scientific definition applies for optics, mineralogy, hydrology, etc. Scientists draw a distinction between the transparency of an object (e.g. a glass, i.e. a container made of glass) and of a medium (e.g. air, water).

Transparency of a medium is a prerequisite of knowledge, an ontological precondition of our visual perception of objects: we can see only those things that are immersed into a transparent medium. Hence, transparency enables the act of vision.

Vision is a neuro-cognitive process that takes the light in our eyes (part of the brain that has been exteriorized in the process of phylogenesis) as input. It is a complex yet fast process organizing meaningless patches of light on the retina into the objects we perceive, i.e. objects with potentially meaningful properties such as shape and spatial arrangement of parts. In simpler words, when we look at a scene, the objects we perceive constitute the output of vision not its input.

Transparency of an object or medium is a scalar property graduating from totally transparent through turbid to opaque/non-transparent.

The transparency of the medium between the observer and the object is the basis for metaphoric transpositions of the meaning of the term 'transparency' as it is used in the humanities, for example:

- $\quad$ in social psychology, transparency behavior is a metaphor implying visibility in contexts related to the behavior of individuals or groups;

- $\quad$ in philosophy, transparency is a metaphor applied to a state in which the subject can be aware of being in that state;

- $\quad$ social transparency is a set of policies that allow citizens to access information held by authorities: 
- $\quad$ linguistic transparency is defined as rhetoric to suit the widest possible audience without losing relevant information, etc.

It can be seen that each of these definitions implies the idea of a boundary:

- $\quad$ in psychology - between the observer and the observed (individuals or groups);

- $\quad$ in philosophy - between the 'inner' and the 'outer' selves;

- $\quad$ in social sciences - between citizens and authorities, etc.

In linguistics the boundary is of a somewhat different nature - it is the boundary either between the extralinguistic world and the content of the sign or between its users; in each case, the boundary is equivalent to the sound/written envelope, or linguistic form.

Thus, a distinction can be drawn between the transparency of the real and the ideal/ virtual/potential. The latter can be subdivided into non-symbolic (the subject-matter of political, psychological and philosophic discourses) and symbolic (the subject-matter the discourses of fine arts, literature and linguistics)

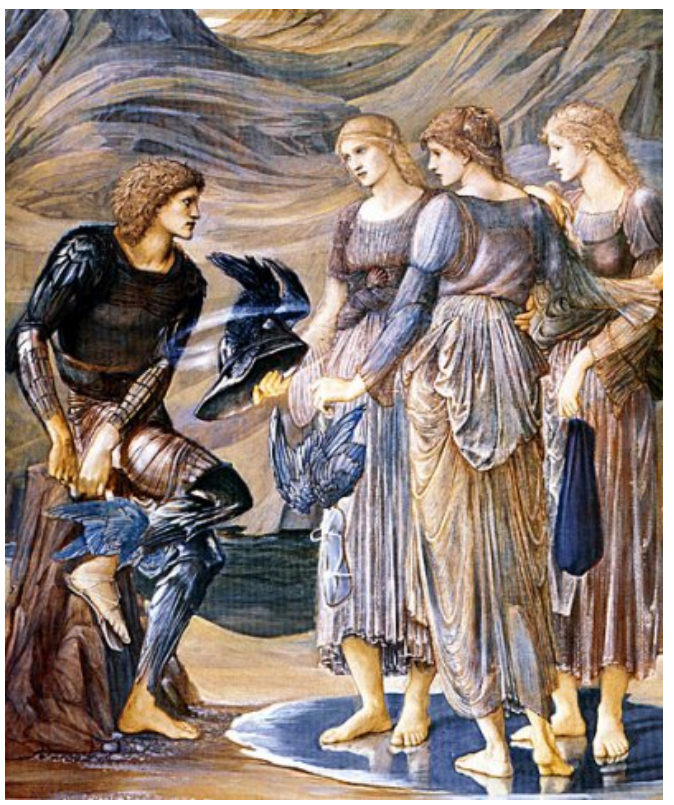

Transparent Material Objects. Since time immemorial people been intrigued and enticed by the prospect of acquiring the power of making things totally transparent / invisible. Historically, the invisibility cap/cloak; helm/cap of darkness (Rus. шапканевидимка) comes first. When Perseus came near the Hera's golden apple garden, the Nymphs of the West gave him a polished bronze shield to see the reflected image of Medusa and not her true face, a sickle shaped sword to cut her head off and a Cap of Darkness to make himself invisible to the Gorgons. A more up-to-date version of the invisibility cloak is the one used by Harry Potter when the boy explored the off-limit corners of Hogwarts. 
Today these fictional cloaks are giving way to true miracles of technology. The picture to the right shows a coat called "Optical Camouflage" which makes the person who wears it as literally vanish into the thin air. It was developed in 2003 in one of the labs of the University of Tokyo.
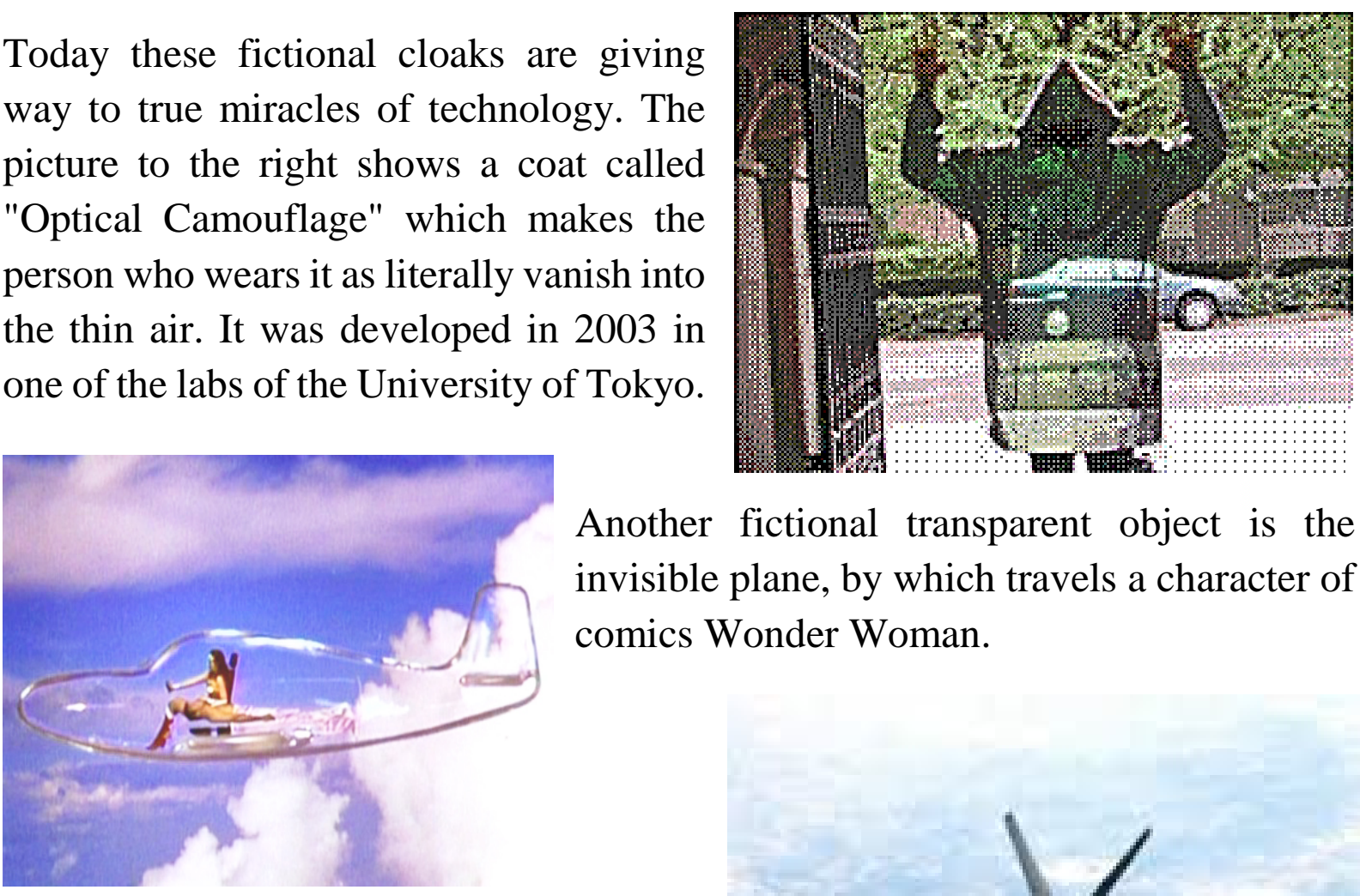

Another fictional transparent object is the invisible plane, by which travels a character of comics Wonder Woman.

Not many people have actually seen a military 'invisible plane'. Stealth aircraft are designed to avoid detection using a variety of advanced technologies that reduce reflection/emission of any kind of irradiation.

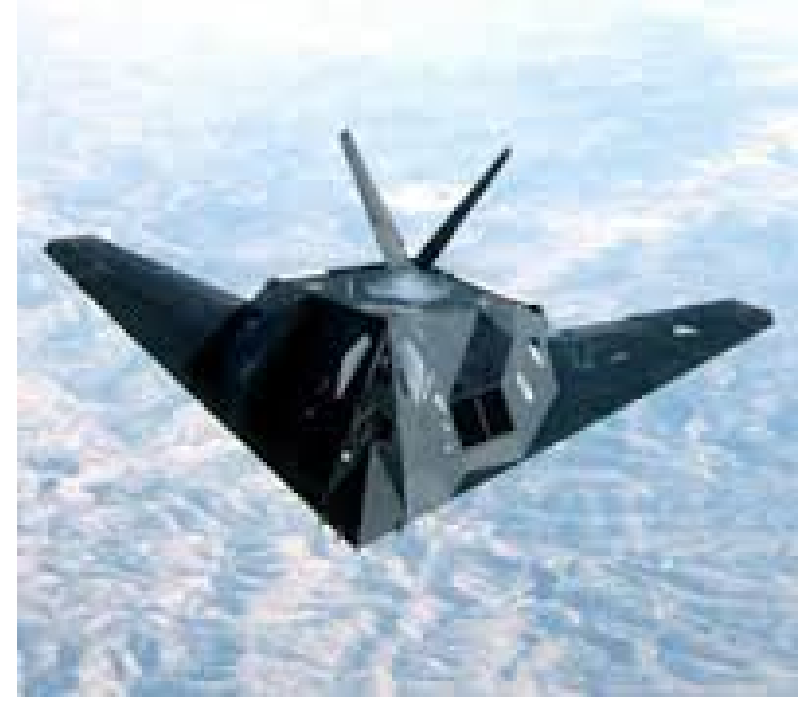

Transparent / glass / see-through frogs have been bred by Japanese scientists for educational purposes. Rather than getting killed for dissection in class, transparent frogs allow students to see all the internal organs in action.

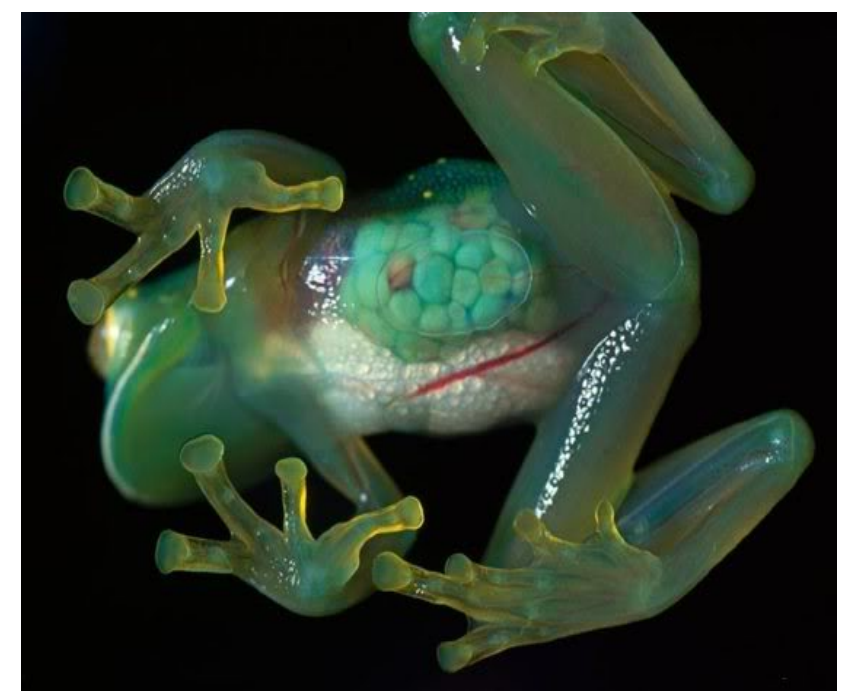




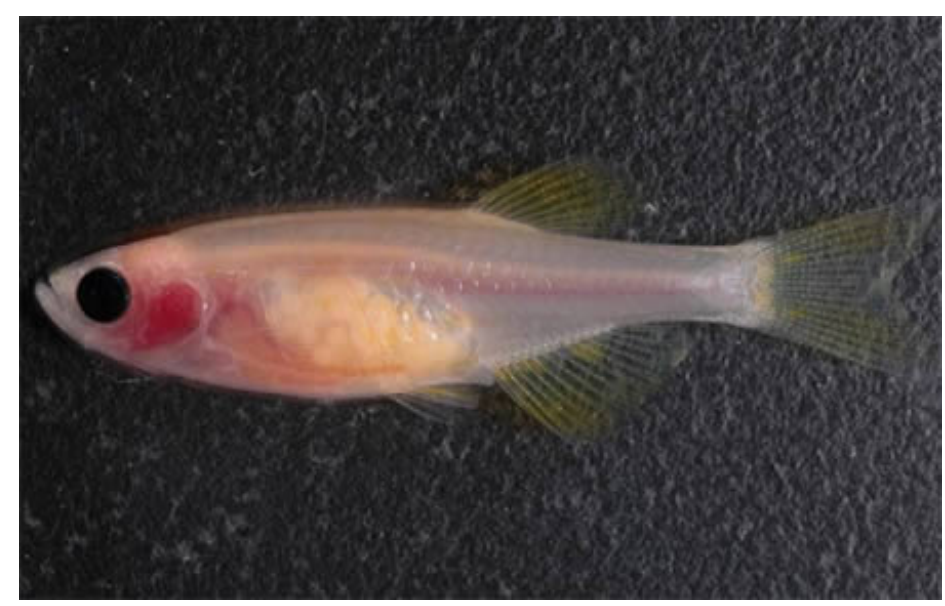

Transparent / glass / see-through zebrafish (Brachydanio rerio) was bred in 2008 by scientists in Boston so they can study disease processes. The transparent fish allow researchers to directly view fish's internal organs and observe processes such as tumor growth in real-time in living organisms.

Overcoming the boundedness of human eye. There are other ways overcoming the boundedness of the human eye which could be said to make things and media invisible:

- $\quad$ night observation device

- $\quad$ radars and periscopes

- $\quad$ probes and sensors

- X-ray

- $\quad$ ultrasonography / ultrasonic scanning

- $\quad$ MRI (Magnetic Resonance Imaging)

Their number and penetration capacity grows with every passing year, and a lot of ethical problems emerge in this connection. 


\section{Transparent Material Media}

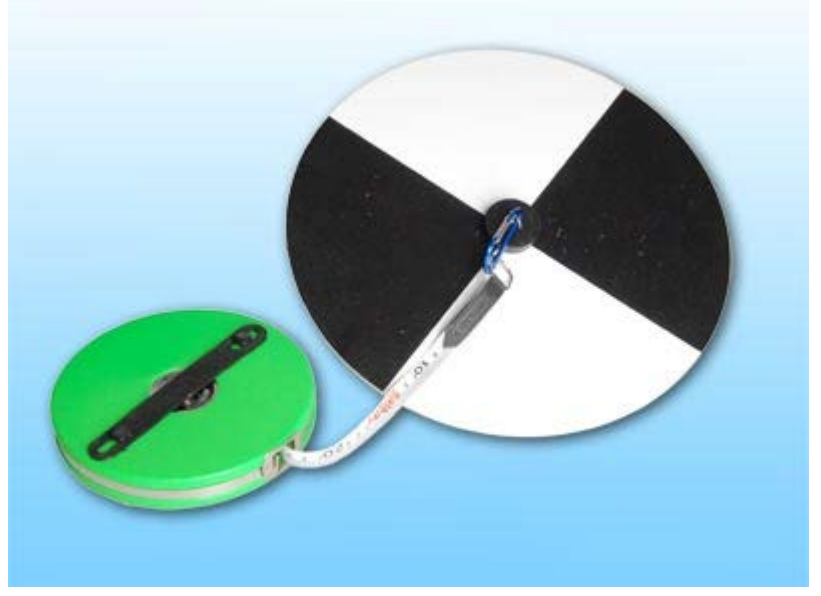

Water: The Secchi disk, as created in 1865 by Angelo Secchi, is a disk $30 \mathrm{~cm}$ in diameter used to measure water transparency in bodies of water. The disc is mounted on a pole or line, and lowered slowly down in the water. The depth at which the disk is no longer visible is taken as a measure of the transparency of the water. This measure is known as the Secchi depth.

It is obvious that water transparency is a characteristic which is directly related to the distance between the observer and the object observed. Thus, it allows one to speak of the thickness of the water layer that separates the observer from the object, or, in a more abstract way, of the thickness of the boundary between them.

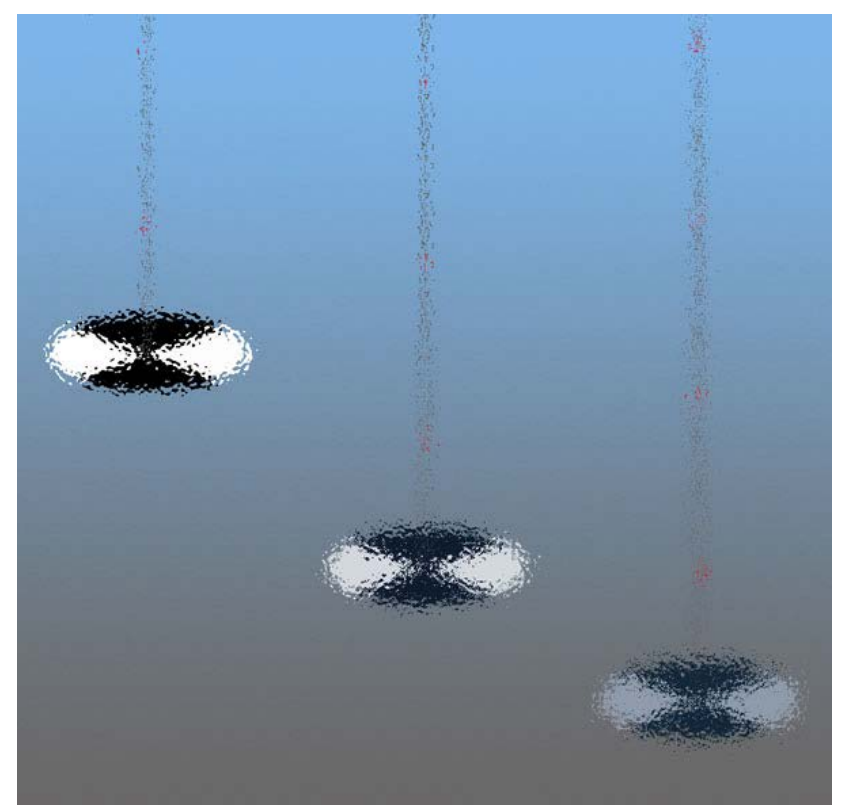

Air: To visually assess the thickness of the air layer which separates the observer and the thing observed is a much more challenging task since air is a much more transparent medium than water. This is how we do it by the rule of thumb. Things in our world have their own surface textures:

- $\quad$ streaks and veins on wood and interweaving threads of a textile / fabric 

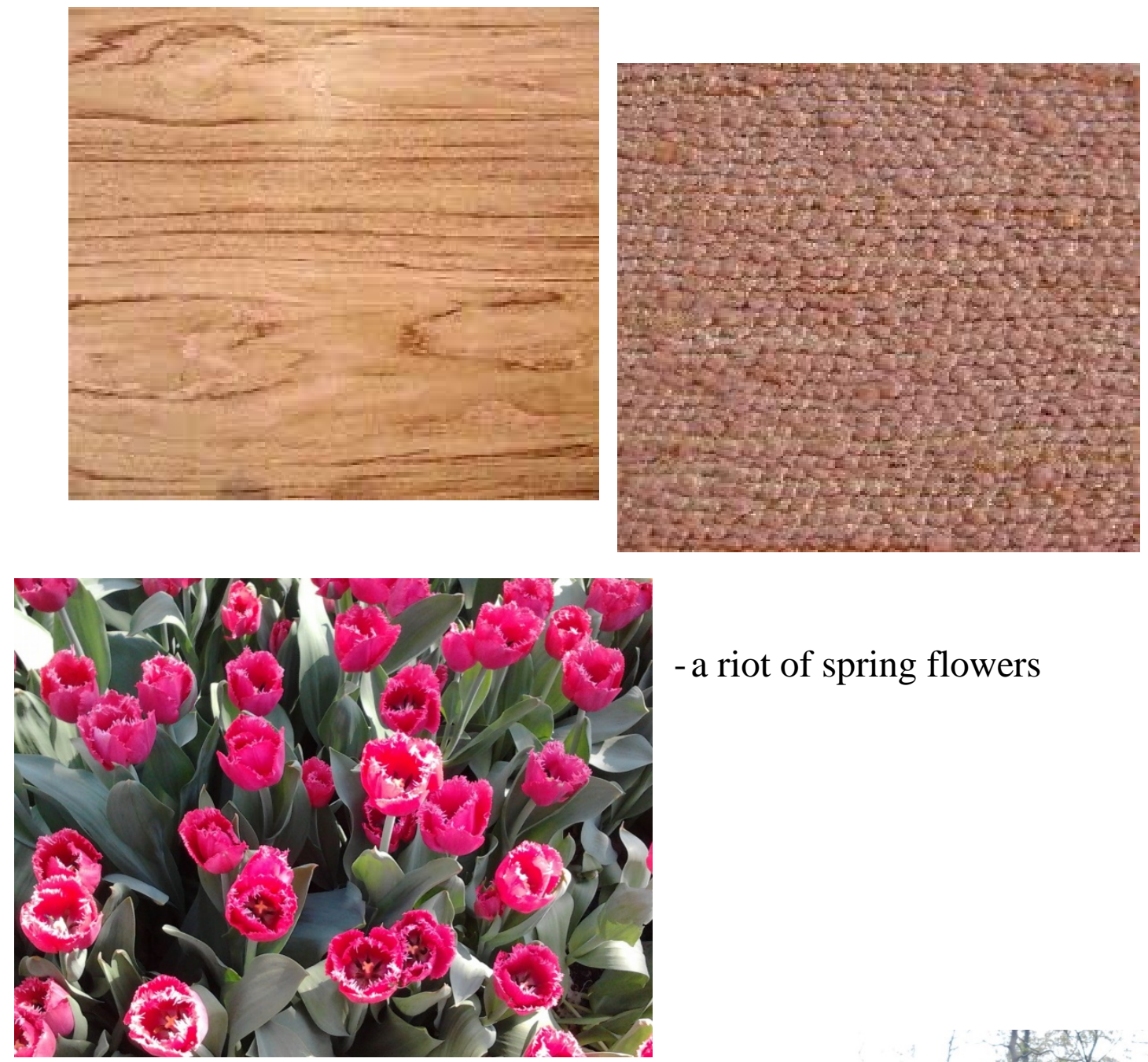

- a riot of spring flowers

an intricate ornament of tree branches
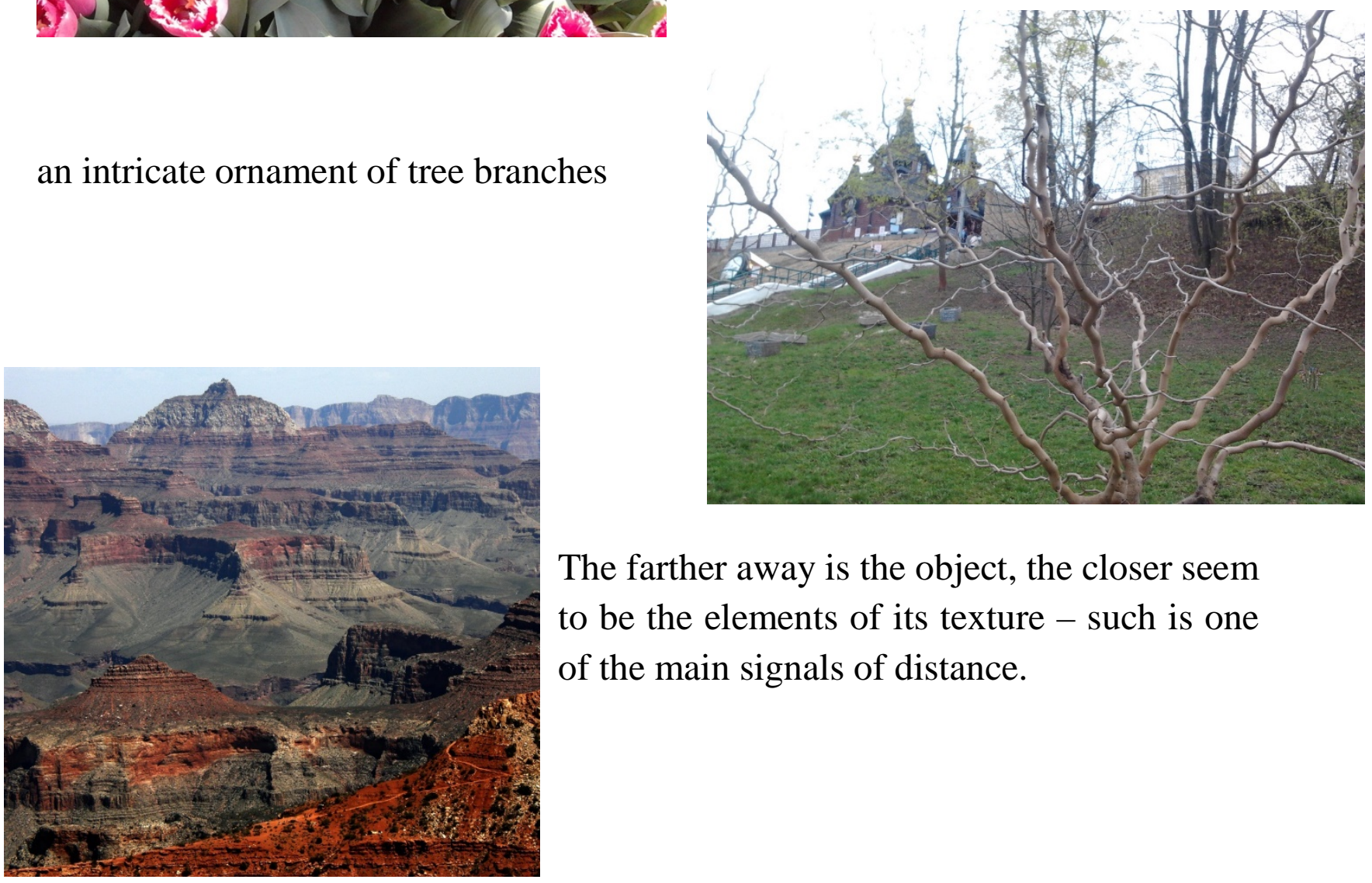

The farther away is the object, the closer seem to be the elements of its texture - such is one of the main signals of distance. 
Professional military men know it very well (they are specially taught) that when the buttons on the enemy's uniform can be seen, the enemy is $200 \mathrm{~m}$ away, when his eyes can are distinguishable, he is 50 meters away.

If there are no textures, if in front of the eye there is something atmospherically homogeneous, then the brain is deprived of one of the main parameters that help it find its bearings / orientate itself. It may result in optical illusions of all kinds.

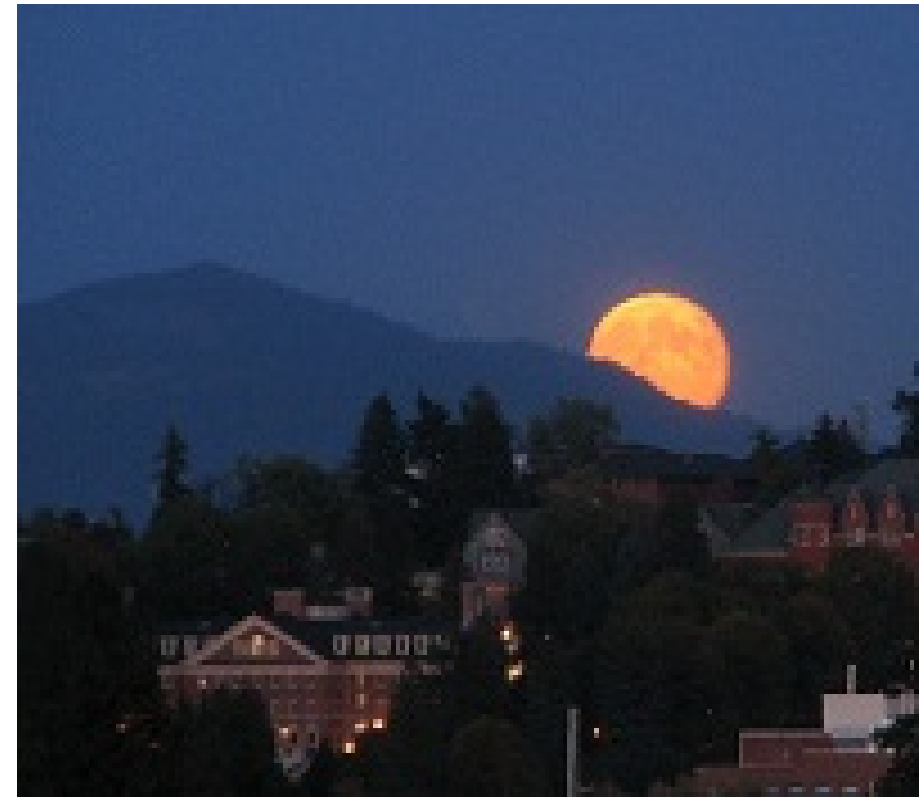

\section{The "Moon Illusion"}

When the moon just begins to rise above the horizon, it seems huge; but as it goes higher, it seems to get smaller. This effect, known as the 'moon illusion', is easy to dispel by holding a coin up to the moon as it travels across the sky. The coin serves as a point of reference, which allows to see that the moon remains the same size despite the way it looks.

The transparency of the medium into which the thing observed is immersed might give rise to deliberate manipulations not only of visual nature, which shall be considered below.

Thus the possible ways of objectivizing the perception of a thing in the transparent medium are:

- $\quad$ to touch it / verify the visual perception in a tactile way;

- $\quad$ to use reliable references to surface textures;

- $\quad$ to observe the things in motion;

- $\quad$ to take into account deficient transparency of the medium (turbidity of water, haze in the air). 
Artistic representation of transparent media. Deficient transparency and surface textures are the two main ways of representing transparency in painting. "Perspective is to painting what the bridle is to the horse, the rudder to a ship $<\ldots>$. There are three aspects to perspective. The first has to do with how the size of objects seems to diminish according to distance: the second, the manner in which colors change the farther away they are from the eye; the third defines how objects ought to be finished less carefully the farther away they are" (Leonardo da Vinci)

There are two main elements in perspective drawing: linear perspective, which deals with the organization of shapes in space, and aerial perspective, which deals with the atmospheric effects on tones and colours. The two kinds of perspective combine in a painting to create an illusion of three dimensions on a twodimensional canvas.

Yet weakening the tones and blurring the distant shapes are not the only ways of creating perspective, i.e. depicting large masses of transparent air. In his famous painting "A Sunday Afternoon on the Island of La Grande Jatte" Seurat depicted people relaxing in a suburban park on an island in the Seine River. He applied the 'pointillism' technique to reflect on canvas the transparency of the luminous air.

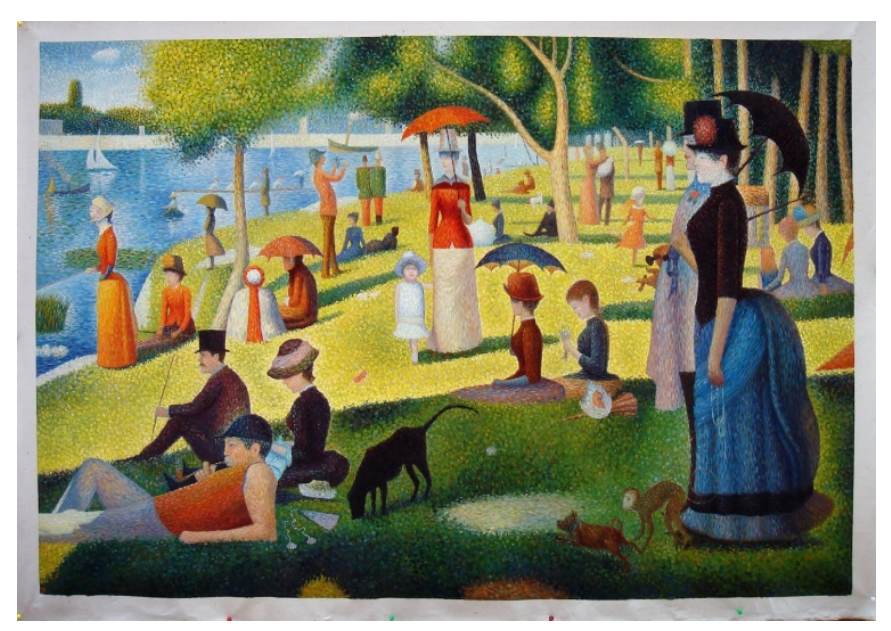

A Sunday Afternoon on the Island of La Grande Jatte by Seurat 
Transparency, obviously, is rendered by using totally different means in bellelettres. Let us consider an extract from Irving Stone's novel "Lust for Life", in which he depicts with verbal means his perception of the picture (or percept) and the feelings he experiences (affect):

"If you'll sit on this stool, Monsieur Van Gogh."

Vincent climbed up on the stool and looked at the canvas spread out before him. It was like nothing he had ever seen before, either in art or life. The scene represented the Island of the Grande Jatte. Architectural human beings, made out of infinitely graduated points of colour, stood up like poles in a Gothic cathedral. The grass, the river, the boats, the trees, all were vague and abstract masses of dotted light. The canvas was done in all the brightest shades of the palette, lighter than those Manet or Degas or even Gauguin dared to use. The picture was a withdrawal into a region of almost abstract harmony. If it was alive, it was not with the life of nature. The air was filled with glittering luminosity, but there was not a breath to be found anywhere. It was a still life of vibrant life, from which movement had been forever banished.

Gauguin stood at Vincent's side and laughed at the expression on his face.

"It's all right, Vincent, Georges's canvases strike everyone that way the first time they look at them. Out with it! What do you think?"

Vincent turned apologetically to Seurat. (Irving Stone “Lust for Life”, p. 286)

To sum up, artistic representation of the transparent air creates an illusion of the viewer being included into the scene depicted. This effect is common for both works of visual art and belle-letters, though they employ totally different means to achieve it.

Transparency of the symbolic boundary in architecture. In a similar way, transparency of a symbolic boundary creates an illusion of observer / perceiver being included into the world: there is no division 'my world - your world'. This is especially obvious in architecture, in which coexist two opposing tendencies the western and the eastern one. The role of symbolic boundaries belongs to walls and windows. 
For example, in Moslem countries, the walls are mostly blank / blind / dead, or with small grated widows which are high above the ground.

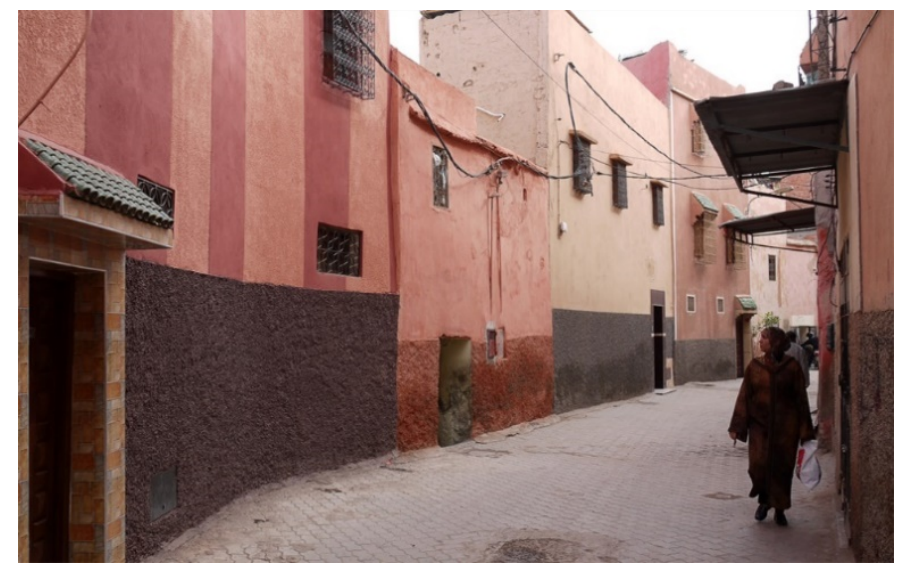

In Northern Europe an opposite tendency prevails.

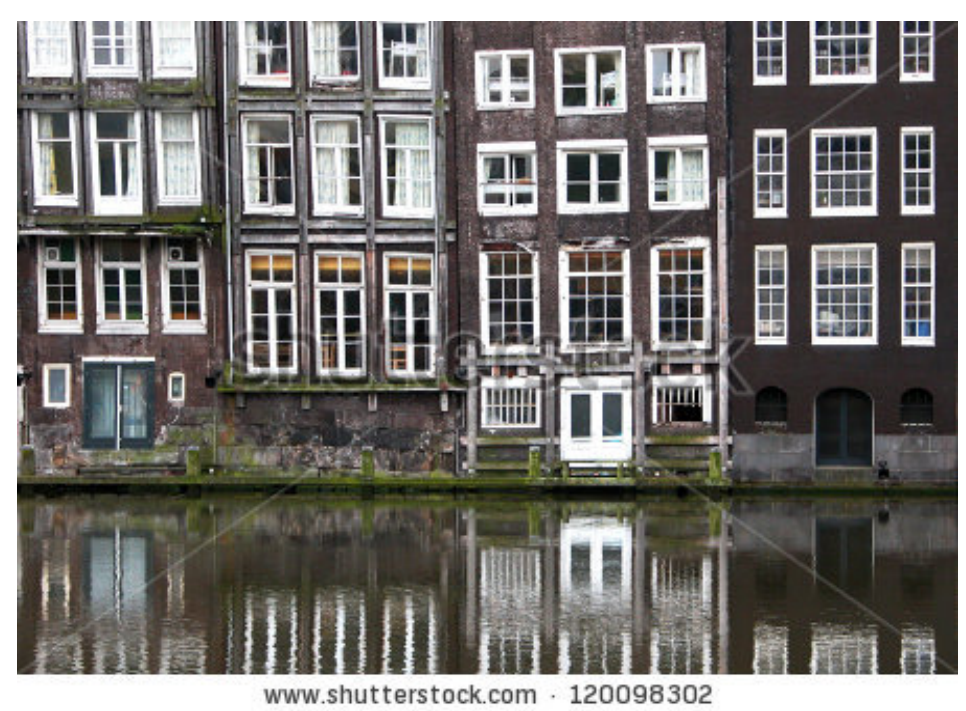

A wall provides - and symbolizes - protection from 'Others', or people around us, while the roof provides protection from heavenly powers (God, the elements).

The history of development of architecture is from non-transparency to transparency, but a theoretician of visual studies A.G. Rappoport doubts whether it is evolution or degradation. 
Social transparency. As the science-fiction author David Brin forecasts in his non-fiction book, 'The Transparent Society' (1998), social transparency, which increases with the advent of low-cost surveillance, communication and database technology, is bound to bring the erosion of privacy, which is one of the fundamental human rights. This means that people must have the power to defend their rights and the ability to detect when they are being abused. Ironically, that will only happen in a world that is mostly open, in which most citizens know most of what is going on, most of the time. It is the only condition under which citizens may have some chance of catching the violators of their freedom and privacy. Privacy is only possible if freedom (including the freedom to know) is protected first.
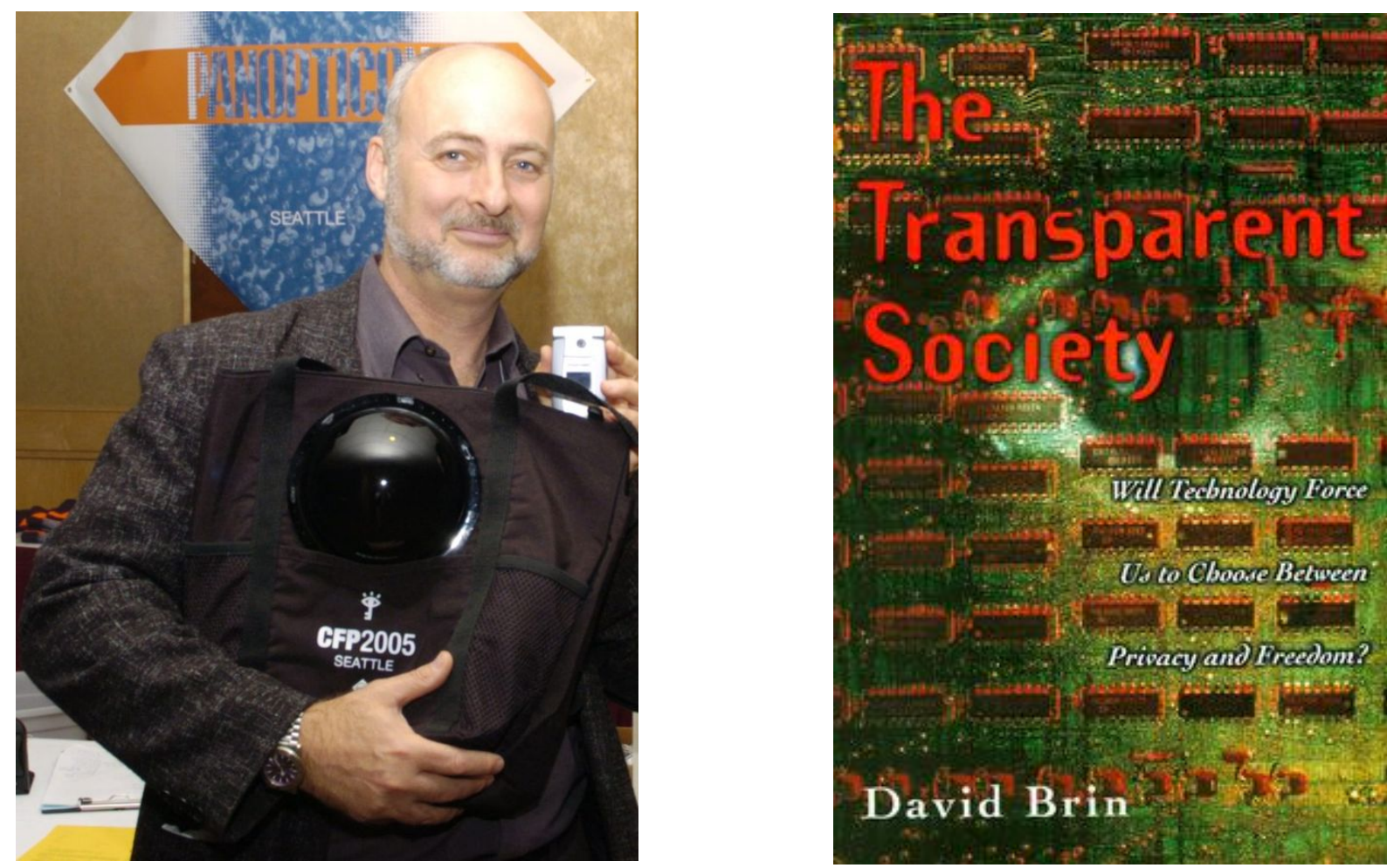

Thus in social sciences there is a movement towards making the information flows more transparent.

Transparency of the linguistic sign. In the light of present-day approaches to viewing language, transparency of the linguistic sign is a fiction: A thought once uttered is untrue (Rus. Мысль изреченная есть ложь - from the poem 'Silentium!') by F. I. Tiutchev (1803-1873). This quote can be interpreted in the following way: the linguistic sign, into which the speaker's thoughts and feelings are packed, is not capable of rendering them in all their complexity. Thus, a 
linguistic sign a priori simplifies the state of things. Moreover, the recipient is sure to interpret the content of the sign according to his own experience/cognitive base. His interpretation is going to digress still further from the sense intended by the speaker.

Meaning does not reside in linguistic units, but is constructed in the minds of the language users. Meaning construction is an on-line mental activity whereby speech participants create meanings on the basis of underspecified linguistic units. The construction of meaning is guided by cognitive principles.

Metaphorically, R. Langacker (1987) likens communication to 'looking at' the world through a window, or a viewing frame/object lens, by both communicants. What appears in this frame/object lens is called in East European linguistics 'the referent situation', and what remains beyond its focus - 'the communicative situation.

In line with the object-matter of our research, R. Langacker's metaphor can be expanded in the following way: in the default case, the object lens is taken to be transparent. But what happens if it does not possess this characteristic?

There are three possible cases of deviation from the etalon case:

(a) «the lens is closed / non-transparent» (no information is given);

(б) «the lens is shifted / transparent» (the relevant information is not given);

(в) «the lens is defocused / dim» (the relevant information is given in a very general way, without the necessary details, or, conversely, with the excessive number of details).

\section{Conclusion}

The lingoecological approach to studying cognitive structures, which presupposes considering them not autonomously, but within a problem situation, is capable of building transdisciplinary bridges between essentially different mental entities, arranging them along a continuum. The polar points of the latter are constituted 
by a scientific (logical) notion and an aesthetic (artistic) concept, which usually presents itself as a percept or an affect, i.e. a concept with the highest degree of subjectivity.

There is another factor that contributes to the arrangement of the mental entities along the scale: it is the criterion of concept's 'authorship'. Universal truths and values belong to the whole humanity, so their authorship is not specific. They are static, 'frozen' entities that may be of interest to a linguist only from a classificatory point of view. Next come group-specific concepts (e.g. ethnically-, gender-marked, etc.), which are characteristic of particular communities of people and can thus be called cultural models, though with certain reservation. They are still static entities, though their contours are less regular that those of scientific concepts (prospects). Concepts of the kind are most favoured by linguists in the post-Soviet scholarly expanse. Finally, there are dynamic, protean aesthetic concepts, which will typically present themselves as affects and percepts. As a rule, they will carry the individual 'signature' of their creator, who can be a writer, a poet, an artist, an architect, a composer, a sculptor, etc.

The mental entities of the three types require different methods for their reconstruction, and yet, they all go under a broad umbrella discipline of universal anthropology.

\section{REFERENCES}

Воркачев, С. Г. (2011). Российская лингвокультурная концептология: современное состояние, проблемы, вектор развития. В: Известия РАН. Серия литературы и языка, 70(5), с.64-74.

Воробьева, О.П. (2013). Концептология в Украине: обзор проблематики. В: Левицкий, А.Э., Потапенко, С.И., ред. Лингвоконцептология: перспективные направления. Луганск: Изд-во ГУ "ЛНУ имени Тараса Шевченко", с.10-37.

Делез, Ж., Гваттари, Ф. (1998). Что такое философия? Пер. с фр. и послесловие С. Н. Зенкина. Москва: Институт экспериментальной социологии, Санкт-Петербург: Алетейя. 
Демьянков, В.3. (2001). Понятие и концепт в художественной литературе и в научном языке. В: Вопросы филологии, 4, с.35-46.

Жаботинская, С. А. (2017). Нарративные политические концепты: методика лингвокогнитивного анализа. В: Петлюченко, Н. В., ред. Конщепты $u$ контрасты. Одесса: Гельветика, с.30-41.

Залевская, А.А. (2014). Интерфейсная теория значения слова: психолингвистический подход. Лондон: IASHE.

Карасик, В. И., Стернин, И. А., ред. (2007). Антология концептов. Москва: Гнозис.

Карасик, В.И. (2009). Языковые ключи. Москва: Гнозис.

Кубрякова, Е.С. (1996). Концепты. В: Краткий словарь когнитивныхх терминов. Москва: Филологический факультет МГУ.

Левицкий, А.Э., Потапенко С. И., ред. (2013). Лингвоконцептология: перспективные направления. Луганск: Изд-во ГУ "ЛНУ имени Тараса Шевченко".

Мартынюк, А. П. (2017). Индивидуальный концепт: природа и метод анализа. В: Петлюченко, Н. В., ред. Концепты и контрасты. - Одесса: Гельветика, с.41-46.

Морозова, Е.И. (2005). Ложь как дискурсивное образование: лингвокогнитивный аспект. Харьков: Экограф.

Никитин, М. В. (2004). Развернутые тезисы о концептах. В: Bonpocbl когнитивной лингвистики. 1, с. 53-64.

Петлюченко, Н. В., ред. (2017). Конщепты и контрасты. Одесса: Гельветика.

Потапенко, С. И. (2013). Концепт как объект когнитивно-дискурсивных студий. В: Левицкий, А.Э., Потапенко С.И., ред. Лингвоконцептология: перспективные направления. Луганск: Изд-во ГУ "ЛНУ имени Тараса Шевченко", с.117-144.

Приходько, А.Н. (2013). Конщепты и конщептосистемы. Днепропетровск: Издательство Белая, Е.А.

Степанов, Ю. С. (1999). Париж - Москва, весной и утром .... В: Серио, П., ред. Квадратура смысла: франиузская школа анализа дискурса. Москва: Прогресс, с. 3-11. 
Степанов, Ю. С. (2007). Конщепты. Тонкая пленка циивиизации. Москва: Языки славянских культур.

Damasio, A. R. (1994). Descartes' Error. Emotion, Reason, and the Human Brain. New York: Avon Books.

Holland, D. C., Quinn, N., eds. (1987). Cultural Models in Language and Thought. Cambridge: Cambridge University Press.

Johnson-Laird, P.N. (1983). Mental models. Cambridge: Cambridge University Press.

Lakoff, G. (1987). Women, fire and dangerous things: What categories reveal about the mind. Chicago-London: The University of Chicago Press.

Langacker, R.W. (1987). Foundations of cognitive grammar. Vol. I: Theoretical Prerequisites. Stanford: Stanford University Press.

Morozova, O. (2017). Transparency across semiotic modes: An ecological stance. In: Chrzanowska-Kluczewska, E., Vorobyova, O., eds. Language - literature the arts: A cognitive-semiotic interface. Frankfurt am Main: Peter Lang, pp.4968.

Ruiz de Mendoza, F. J., Galera Masegosa, A. (2014). Cognitive modeling. A linguistic perspective. Amsterdam-Philadelphia: John Benjamins.

Zhabotynska, S. A. (2010). Principles of building conceptual models for thesaurus dictionaries. In: Когніція, комунікація, дискурс, 1, с.75-92.

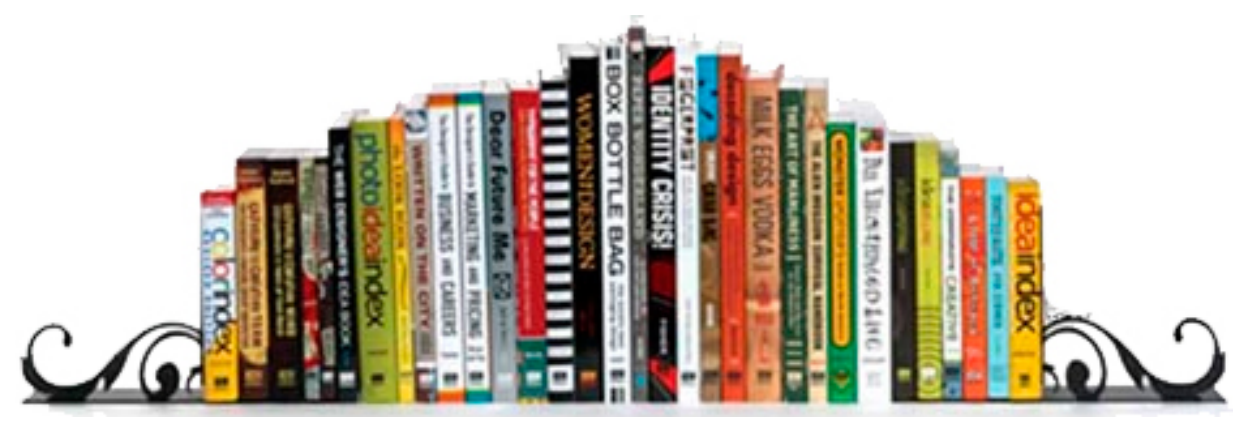

